$$
\begin{aligned}
& \text { بررسى تغيبر ات اجتماعات كَياهى بعد از جراى شليد دام در دشت كَلبهار در شمال شرق }
\end{aligned}
$$

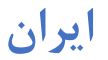

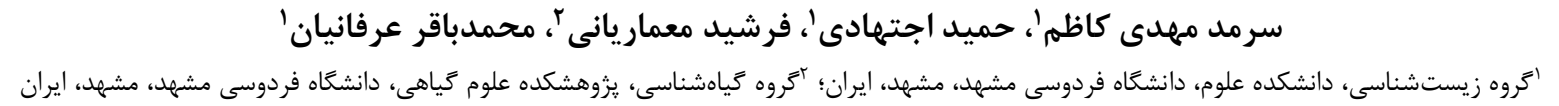

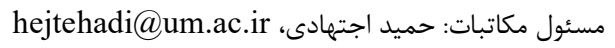

$$
\begin{aligned}
& \text { جكيده. جراى بيش از حد دام اجتماعهاى كياهى را تحت تأثير قرار داده و به عنوان يكى از مهرهترين عوامل تخريب يوشش كياهى در مناطق خشك و نيمه }
\end{aligned}
$$

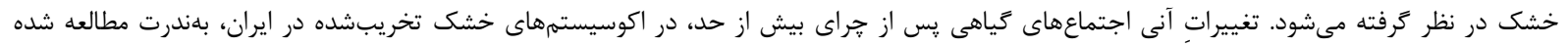

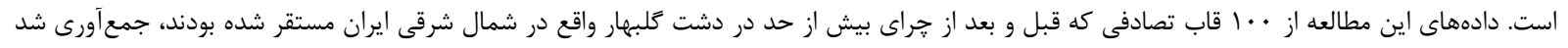

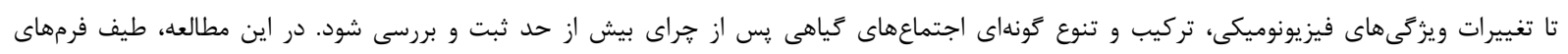

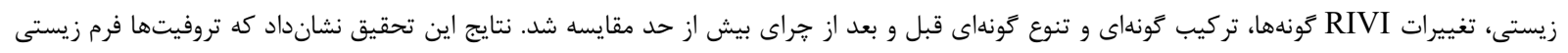

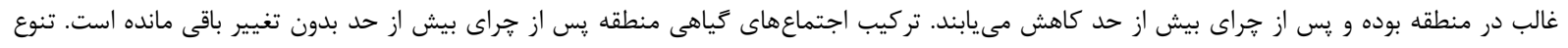

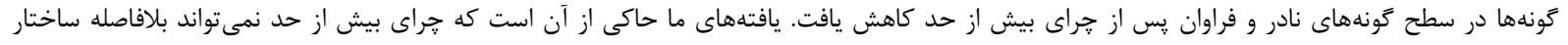

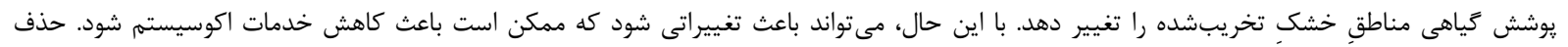

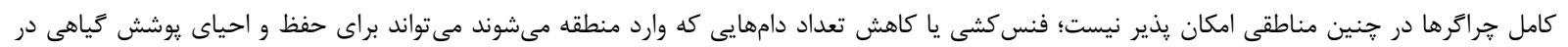

$$
\begin{aligned}
& \text { منطقه استفاده شود } \\
& \text { وازه هاى كليدى. تركيب گَنهاى، تنوع گَنهاى، زمينهاى خشك، فرم زيستى }
\end{aligned}
$$

\title{
Evaluating changes in the plant communities after overgrazing in the Golbahar plain, northeast of Iran
}

\section{Sarmad Mahdi Kadhum¹, Hamid Ejtehadi', Farshid Memariani² \& Mohammad Bagher Erfanian $^{1}$}

${ }^{1}$ Department of Biology, Faculty of Science, Ferdowsi University of Mashhad, Mashhad, Iran; ${ }^{2}$ Department of Botany, Research Center for Plant Sciences, Ferdowsi University of Mashhad, Mashhad, Iran

Corresponding author: Hamid Ejtehadi, hejtehadi@um.ac.ir

\begin{abstract}
Overgrazing affects plant communities, and is a significant disturbance factor in arid and semi-arid regions. The immediate changes of plant communities after overgrazing in the disturbed arid ecosystems of Iran have been poorly studied. We recorded data from 100 random samples before and after overgrazing in the Golbahar plain located in the northeastern Iran to determine the changes in the plant physiognomic, species composition, and diversity after overgrazing. We compared life-forms spectra, change in the RIVI of the recorded plant species, species composition, and species diversity before and after the grazing. Our results showed that therophytes were the dominant life-form in the area, and decreased after overgrazing. The community composition of the area remained unchanged after overgrazing. Species diversity at the level of rare and frequent species reduced after overgrazing. Our findings implied that overgrazing could not immediately affect the community structure of degraded arid areas. However, it causes changes that might reduce ecosystem services in them. It is not possible to completely exclude grazers in such areas, fencing or reducing the number of the livestock entries should be applied to restore the vegetation in the area.
\end{abstract}

Keywords. arid lands, life-form, species composition, species diversity 


\section{INTRODUCTION}

Approximately one-third of earth's habitats are located in the arid and semi-arid lands (Muenchow et al., 2013). These habitats contain a significant part of world biodiversity and also a significant part of world livestock grazers. Anthropogenic disturbances, including overgrazing, are the major threats to the natural ecosystems of these areas. Desertification is the consequence of these disturbances. It is a major ecological problem that affects vegetation and soil in these areas (Jeddi \& Chaieb, 2010; Muenchow et al., 2013).

Livestock overgrazing is the primary cause of disturbance in arid regions (Fallah et al., 2017; Jeddi \& Chaieb, 2010; Tadey \& Souto, 2016). Plant biomass reduction, a decline in the offspring production, plant community composition alteration, soil erosion, and reduced soil infiltration are the frequently reported effects of overgrazing in arid and semi-arid ecosystems (Eccard et al., 2000; Fallah et al., 2017; Jeddi \& Chaieb, 2010; Tadey \& Souto, 2016).

In northeastern Iran, overgrazing has been ongoing for many centuries due to the local population and pilgrims' demands (Erfanian et al. 2019a). A long history of overgrazing has induced land degradation that resulted in plant community alteration as well as soil erosion. Consequently, plant species diversity in this area might have been decreased, or species are being endangered (Memariani et al., 2016a; Maleki Sadabadi et al., 2017; Behroozian et al., 2019; Rahmanian et al., 2020). Memariani et al. (2016b) published the checklist and conservation status of the endemic species of the Khorassan-Kopet Dagh floristic province in northeastern Iran. Despite the recurrent disturbance, grazing exclusion is not applied in the area. As a result, plant communities are affected by this disturbance every year.

Theoretical and empirical studies suggest that arid ecosystems would be relatively immune to the effects of grazing, especially if these ecosystems have a long history of grazing (Cingolani et al., 2005; Milchunas et al., 1988; Salgado-Luarte et al., 2019; Sullivan \& Rohde, 2002). For example, Sullivan and Rohde (2002) argued that overgrazing in the disturbed areas could not lead to progressive degradation because of the presence of unpalatable species. However, Illius \& O'Connor (1999) reported that in the arid areas, overgrazing would lead to increased degradation. Plant communities do not significantly change in the rangelands with a long history of grazing because the resilience mechanisms allow for reversible changes associated with grazing intensity (Cingolani et al., 2005).

To evaluate the effects of overgrazing on plant communities of a disturbed area, we analyzed plant life-forms, species composition, and the diversity before and after overgrazing in the Golbahar plain (northeastern Iran). The area represents highly degraded rangeland that are consecutively overgrazed. Thus, we could evaluate the immediate response of plant communities to overgrazing in degraded arid rangeland and answer the following questions: (1) what were the effects of overgrazing on the physiognomy of plant communities? (2) Was there any structural and composition difference in plant communities after overgrazing? (3) What were the effects of overgrazing on species diversity at the level of rare, frequent, and dominant species?

\section{MATERIALS AND METHODS \\ Study area}

The Golbahar plain, located in the west of Mashhad, is a part of the northeastern slopes of the Binalood Mountains and covers ca. 11000 ha surface area (Eftekhari et al., 2014). The area has an elevation range of 1165-1300 $\mathrm{m}$ above sea level (Fig. 1). The Golbahar plain has an arid climate. The mean annual precipitation and mean annual temperature of the area are $204 \mathrm{~mm}$ and $14.7^{\circ} \mathrm{C}$, respectively (Iran Meteorological OrganizationRazavi Khorassan portal, 2018). The area has been subjected to overgrazing as pasture by the sheep and goats for many years. The soil of the area is mainly formed by alluvial fans (Geological Survey of Iran, 1986). It has a loam/clay-loam texture. This area has a deep soil profile (Eftekhari et al., 2014).

\section{Data collection}

Plant species data were collected in a two-phase survey to compare the vegetation status of the area after and before overgrazing. The first phase (before overgrazing) conducted in May 2017, and the second phase (after overgrazing) performed in June 2017. Data was collected by using 100 randomlyplaced quadrats in each phase. Because of the degraded nature of the vegetation in the area, the 100 was considered satisfactory. Furthermore, we used the coverage-based approaches to evaluate the species diversity of the area to ensure that the number of samples was not affecting our inferences (Chao et al., 2014; Chao \& Jost, 2012; Erfanian et al., 2019a). We recorded the floristic list and canopy cover (\%) for each plant species in 1 x 1 m quadrats.

\section{Data analysis}

The Raunkiaer's life-form spectrum was drawn for the plant species before and after grazing using the ggplot2 package (Wickham, 2009) in R ver. 3.5 (R Core Team, 2018). The Relative Importance Value Index (RIVI) of the recorded species was calculated for each phase. Transformation-based principal component analysis (tb-PCA) was used to visualize the changes in the species composition of the area (Legendre \& Legendre, 2012). To do this, we used the approach described by Erfanian et al. (2019b). 


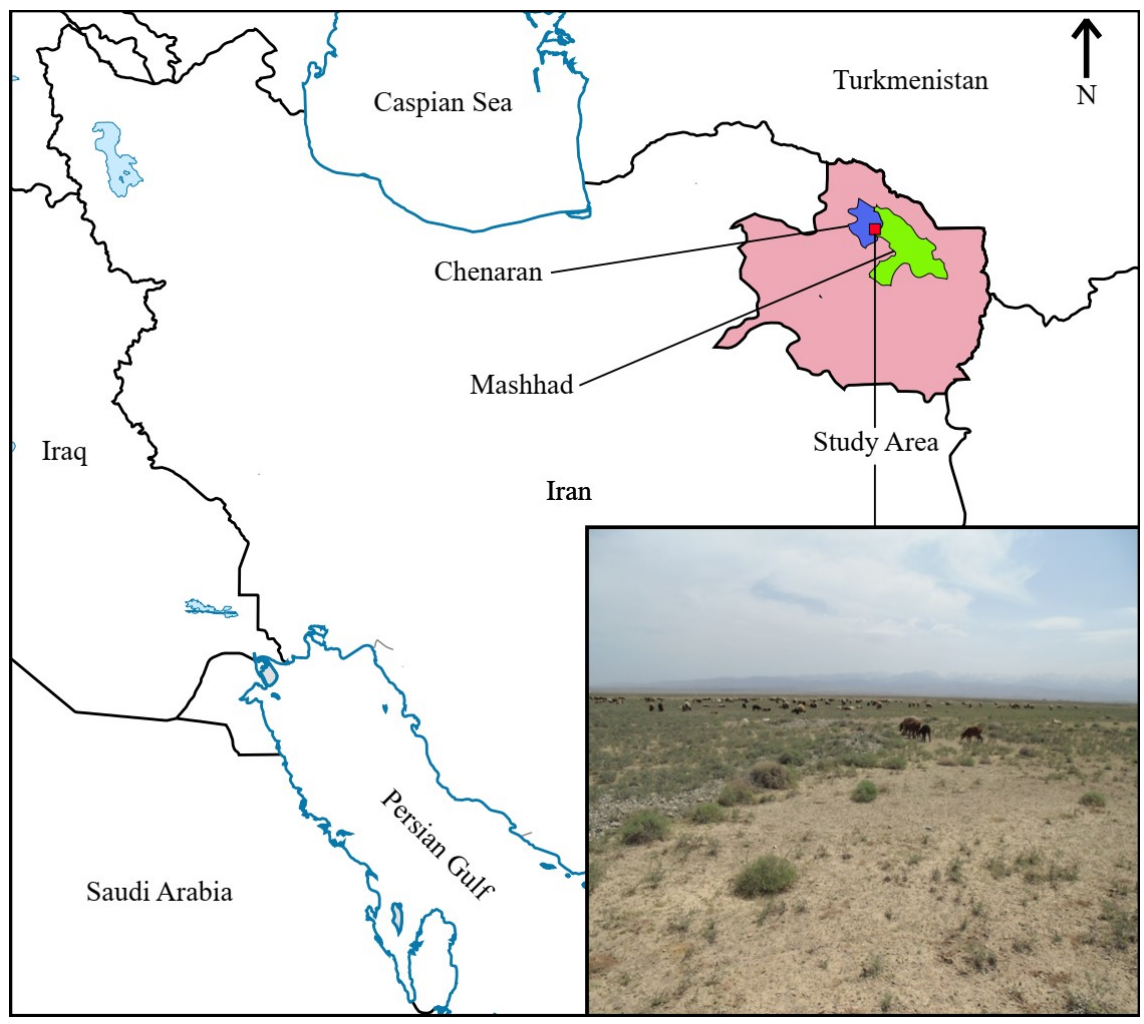

Figure 1. Geographical position and a landscape photo of the study area. The pink shaded area is Khorassan Razavi Province, Iran.

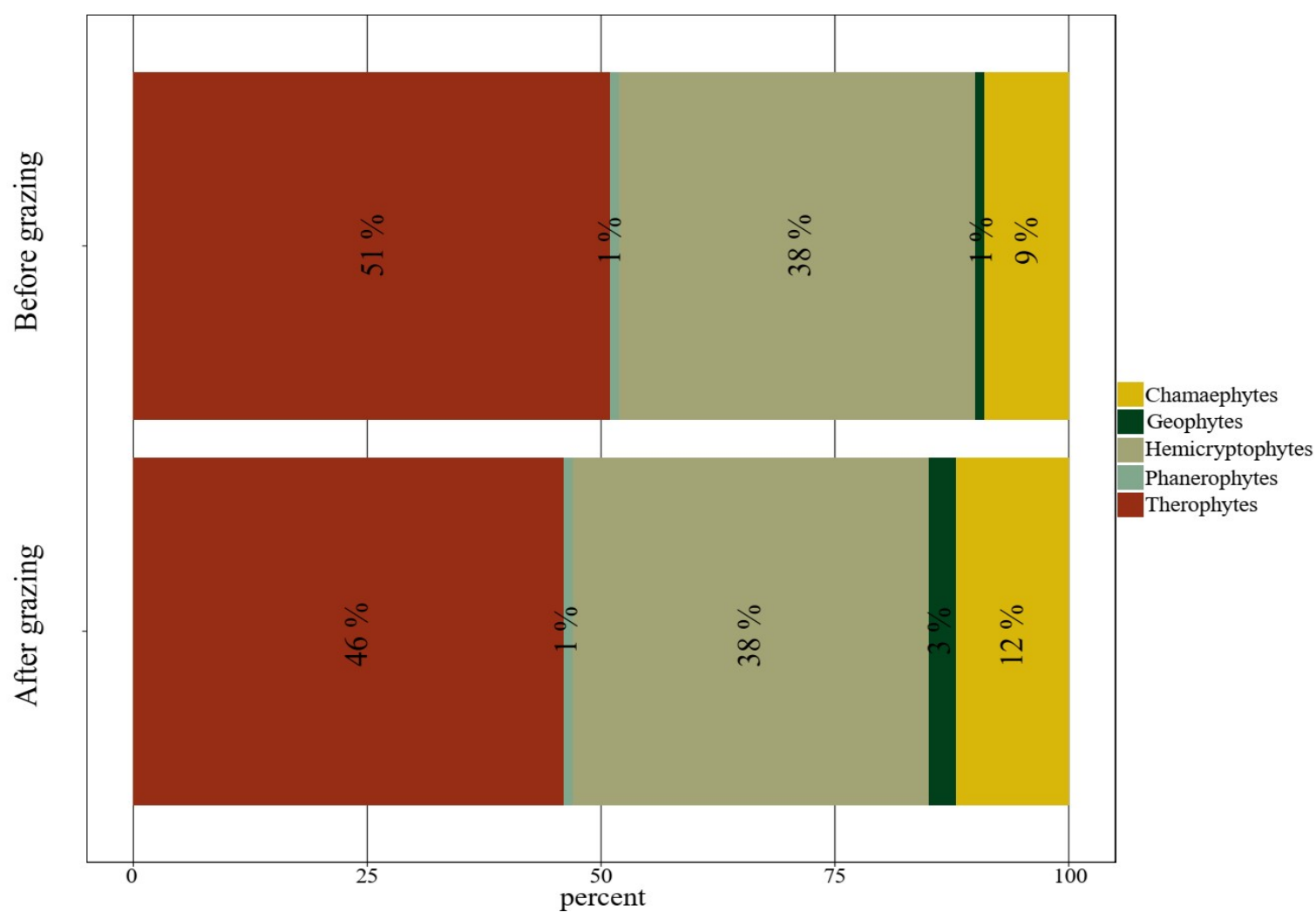

Figure 2. Raunkiær's life-form spectrum for the before and after overgrazing phases. Therophytes were the dominant life-form in the area. 
To compare the species diversity before and after overgrazing, we used Hill diversity indices. These indices are considered as the standard framework of diversity calculations (Chao et al., 2014a, b; Ellison, 2010). The coverage-based approach was selected to eliminate the effects of unequal sampling completeness on the biodiversity results (Chao \& Jost, 2012). Hill numbers of the zero ( $\mathrm{q}=0$, species richness), first ( $\mathrm{q}=1$, exponential of Shannon diversity), and second-order ( $\mathrm{q}=2$, Reciprocal of Simpson index) were calculated. These indices considered species diversity at the level of rare, frequent, and dominant species of plant communities, respectively (Erfanian et al., 2019a, Atashgahi et al., 2018b). We used the iNEXT package (Hsieh et al., 2016) to calculate these indices. We draw the coverage-based rarefaction and extrapolation curves for each of these indices. The $95 \%$ confidence interval (CI) of each curve was calculated by using the bootstrapping procedure of this package.

\section{RESULTS}

Therophytes were the dominant life-form in the study area. This life-form was recorded in a lower percent after overgrazing. Only one species (i.e.,
Capparis spinosa L.) with a phanerophyte life-form was recorded in the before and after overgrazing phases. The life-form spectra of the two phases are shown in Figure 2.

A list of the endemic/subendemic species of the area is presented in table 1. Two species (i.e., Cousinia verbascifolia Bunge and Echinops chorassanicus Bunge) are endemic to Iran.

RIVI reuslts are presented in Table 2. This results revealed that most of the annual species showed a decreased RIVI. Also, unpalatable plants showed a general increase in RIVI after overgrazing.

However, the diagram of tb-PCA revealed that there is no evident separation among the samples from before and after overgrazing. This diagram is shown in Figure 3. Species richness (Fig. 4, $q=0$ column) was significantly decreased after overgrazing. The same result was observed for the exponential of Shannon diversity (Fig. 4, q=1 column). There was no significant difference between before and after overgrazing phases, as long as the reciprocal of the Simpson index is considered (Fig. 4, $\mathrm{q}=2$ column).

Table 1. Endemic and sub-endemic species of the study area. Abbreviations: Turkmenistan: Turkm., Afghanistan: Afgh.

\begin{tabular}{|c|c|}
\hline Species & Geographical distribution \\
\hline Astragalus pellitus Bunge & Iran- Turkm.- Afgh. \\
\hline Cousinia verbascifolia Bunge & Iran \\
\hline Echinops chorassanicus Bunge & Iran \\
\hline Cousinia afghanica C.Winkl. & Iran- Afgh. \\
\hline Astragalus suluklensis Freyn. \& Sint. & Iran- Turkm. \\
\hline Astragalus sumbari Popov & Iran- Turkm. \\
\hline Cleome khorassanica Bunge \& Bien. ex Boiss. & Iran- Turkm. \\
\hline Cousinia eryngioides Boiss. & Iran- Turkm. \\
\hline Acanthophyllum korshinskyi Schischk. & Iran- Turkm.- Afgh. \\
\hline Artemisia ciniformis Krasch. \& Popov ex Poljakov & Iran- Turkm.- Afgh. \\
\hline Astragalus macrobotrys Bunge & Iran- Turkm.- Afgh. \\
\hline Cousinia congesta Bunge & Iran- Turkm.- Afgh. \\
\hline Eryngium bungei Boiss. & Iran- Turkm.- Afgh. \\
\hline Erysimum aitchisonii O.E.Schulz & Iran- Turkm.- Afgh. \\
\hline Iris kopetdagensis (Vved.) B.Mathew \& Wendelbo & Iran- Turkm.- Afgh. \\
\hline Prangos latiloba Korovin & Iran- Turkm.- Afgh. \\
\hline
\end{tabular}


Table 2. Changes in the relative importance value indices (RIVI) of the recorded plant species of the study area for the before and after overgrazing phases. The 0 indicates that the species was not recorded in the studied phase. Therophytes: Th, Chamaephytes: Ch, Hemicryptophytes: He, Geophytes: Geo, Phanerophytes: $\mathrm{Ph}$.

\begin{tabular}{|c|c|c|c|c|c|}
\hline Family & Species & Life-form & $\begin{array}{l}\text { RIVI } \\
\text { before }\end{array}$ & $\begin{array}{l}\text { RIVI } \\
\text { after }\end{array}$ & status \\
\hline \multirow{7}{*}{ Amaranthaceae } & Amaranthus blitoides S.Watson & $\mathrm{Th}$ & 0.329 & 0.931 & Increased \\
\hline & Amaranthus retroflexus L. & Th & 0.149 & 0.000 & decreased \\
\hline & Atriplex tatarica $\mathrm{L}$. & $\mathrm{Th}$ & 0.000 & 0.465 & Increased \\
\hline & Ceratocarpus arenarius L. & $\mathrm{Th}$ & 4.972 & 5.311 & Increased \\
\hline & Chenopodium botrys L. & $\mathrm{Th}$ & 0.334 & 0.228 & decreased \\
\hline & Noaea acrocarp (Forssk.) Asch. \& Schweinf. & $\mathrm{Ch}$ & 0.644 & 1.036 & Increased \\
\hline & Salsola kali L. & $\mathrm{Th}$ & 0.577 & 1.781 & Increased \\
\hline \multirow{3}{*}{ Apiaceae } & Eryngium billardieri F.Delaroche & $\mathrm{He}$ & 0.273 & 0.000 & decreased \\
\hline & Eryngium bungei Boiss. & $\mathrm{He}$ & 0.329 & 0.562 & Increased \\
\hline & Foeniculum vulgare Miller & $\mathrm{He}$ & 0.149 & 0.000 & decreased \\
\hline \multirow{21}{*}{ Asteraceae } & Acantholepis orientalis Less. & Th & 0.254 & 0.811 & Increased \\
\hline & Achillea wilhelmsii K. Koch & $\mathrm{He}$ & 0.670 & 0.000 & decreased \\
\hline & Acroptilon repens (L.) DC. & $\mathrm{He}$ & 0.509 & 1.320 & Increased \\
\hline & Artemisia ciniformis Krasch. \& M.Pop. ex pojark & $\mathrm{Ch}$ & 0.180 & 1.179 & Increased \\
\hline & Artemisia scoparia Waldst. \& Kit. & $\mathrm{Ch}$ & 2.063 & 4.215 & Increased \\
\hline & Carthamus oxyacantha M.Bieb. & Th & 0.745 & 2.142 & Increased \\
\hline & Centaurea depressa M.Bieb. & $\mathrm{Th}$ & 0.365 & 0.000 & decreased \\
\hline & Centaurea virgata Lam. & $\mathrm{Ch}$ & 1.741 & 2.039 & Increased \\
\hline & Chondrilla juncea L. & $\mathrm{He}$ & 0.000 & 0.793 & Increased \\
\hline & Cichorium intybus L. & $\mathrm{He}$ & 0.000 & 0.299 & Increased \\
\hline & Cousinia afghanica C.Winkl. & $\mathrm{He}$ & 1.334 & 0.263 & decreased \\
\hline & Cousinia congesta Bunge & $\mathrm{He}$ & 0.665 & 0.000 & decreased \\
\hline & Cousinia eryngioides Boiss. & $\mathrm{He}$ & 0.415 & 0.249 & decreased \\
\hline & Cousinia microcarpa Boiss. & $\mathrm{He}$ & 0.391 & 0.000 & decreased \\
\hline & Crepis sancta (L.) Babcock & $\mathrm{Th}$ & 0.712 & 0.000 & decreased \\
\hline & Cymbolaena griffithii (A.Grey) Wagenitz & $\mathrm{Th}$ & 0.111 & 0.000 & decreased \\
\hline & Echinops chorassanicus Bunge & $\mathrm{He}$ & 1.087 & 2.055 & Increased \\
\hline & Echinops leiopolyceras Bornm. & $\mathrm{He}$ & 0.428 & 0.719 & Increased \\
\hline & Gundelia tournefortii $\mathrm{L}$. & $\mathrm{He}$ & 0.547 & 0.000 & decreased \\
\hline & Koelpinia linearis Pall & $\mathrm{Th}$ & 0.260 & 0.000 & decreased \\
\hline & Lactuca glauciifolia Boiss. & Th & 0.000 & 0.385 & Increased \\
\hline
\end{tabular}


Table 2. continued.

\begin{tabular}{|c|c|c|c|c|c|}
\hline & & & & & \\
\hline & Lactuca orientalis Boiss. & $\mathrm{Ch}$ & 3.064 & 2.916 & Decreased \\
\hline & Lactuca serriola $\mathrm{L}$. & $\mathrm{He}$ & 0.000 & 0.613 & Increased \\
\hline & Launaea acanthodes (Boiss.) Kuntze & $\mathrm{He}$ & 0.609 & 3.481 & Increased \\
\hline & Onopordon heteracanthum C. A. Mey. & $\mathrm{He}$ & 2.797 & 1.914 & decreased \\
\hline & Picnomon acarna (L.) Cass. & Th & 0.000 & 1.338 & Increased \\
\hline & Pulicaria gnaphalodes (Vent.) Boiss. & $\mathrm{Ch}$ & 1.056 & 2.688 & Increased \\
\hline & Thevenotia persica DC. & Th & 0.149 & 0.000 & decreased \\
\hline & Tragopogon graminifolius DC. & $\mathrm{He}$ & 0.180 & 0.000 & decreased \\
\hline & Xanthium brasilicum Vell. & Th & 0.180 & 0.755 & Increased \\
\hline \multirow{5}{*}{ Boraginaceae } & Anchusa italica Retz & $\mathrm{He}$ & 0.273 & 0.000 & decreased \\
\hline & Echium italicum L. & $\mathrm{He}$ & 0.578 & 0.000 & decreased \\
\hline & Heliotropium europaeum L. & Th & 6.895 & 7.048 & Increased \\
\hline & Nonea caspica (Willd.) G.Don. & Th & 0.775 & 0.000 & decreased \\
\hline & Trichodesma incanum (Bunge.) A.DC. & $\mathrm{He}$ & 0.305 & 0.000 & decreased \\
\hline \multirow{5}{*}{ Brassicaceae } & Alyssum linifolium Steph. ex Willd. & $\mathrm{Th}$ & 2.498 & 0.657 & decreased \\
\hline & Erysimum badghisi (Korsh.) Lipsky & $\mathrm{He}$ & 0.105 & 0.546 & Increased \\
\hline & Goldbachia laevigata (M.Bieb.) DC. & $\mathrm{Th}$ & 0.118 & 0.000 & decreased \\
\hline & Malcolmia africana (L.) W.T.Aiton & Th & 1.784 & 0.315 & decreased \\
\hline & Sisymbrium altissimum L. & Th & 0.242 & 0.000 & decreased \\
\hline \multirow{2}{*}{ Capparaceae } & Capparis spinosa L. & $\mathrm{Ph}$ & 0.305 & 3.225 & Increased \\
\hline & Cleome coluteoides Boiss. & $\mathrm{He}$ & 0.516 & 0.000 & decreased \\
\hline \multirow{2}{*}{ Caprifoliaceae } & Scabiosa olivieri Coult. & $\mathrm{Th}$ & 0.328 & 1.014 & Increased \\
\hline & Scabiosa rotata M.Bieb. & $\mathrm{Th}$ & 0.111 & 0.776 & Increased \\
\hline \multirow{5}{*}{ Caryophyllaceae } & Acanthophyllum korshinskyi Schischk. & $\mathrm{Ch}$ & 2.905 & 0.334 & decreased \\
\hline & Gypsophila bicolor (Freyn \& Sint.) Grossh. & $\mathrm{He}$ & 0.305 & 0.000 & decreased \\
\hline & Holosteum glutinosum Fisch. \& C.A.Mey & $\mathrm{Th}$ & 0.217 & 0.000 & decreased \\
\hline & Minuartia meyeri (Boiss.) Bornm. & Th & 0.334 & 0.000 & decreased \\
\hline & Silene chaetodonta Boiss. & $\mathrm{Th}$ & 0.118 & 0.000 & decreased \\
\hline \multirow{2}{*}{ Convolvulaceae } & Convolvulus arvensis L. & $\mathrm{He}$ & 0.000 & 0.334 & Increased \\
\hline & Convolvulus pilosellifolius Desv. & $\mathrm{He}$ & 0.242 & 0.000 & decreased \\
\hline Cyperaceae & Carex stenophylla Wahlenb. & $\mathrm{He}$ & 0.000 & 0.475 & Increased \\
\hline \multirow{2}{*}{ Euphorbiaceae } & Chrozophora tinctoria (L.) A.Juss. & Th & 0.000 & 0.491 & Increased \\
\hline & Euphorbia granulata Forssk. & $\mathrm{Th}$ & 0.831 & 0.228 & decreased \\
\hline
\end{tabular}


Table 2. continued.

\begin{tabular}{|c|c|c|c|c|c|}
\hline \\
\hline & Euphorbia szovitsii Fisch \& C.A.Mey. & $\mathrm{Th}$ & 0.303 & 0.000 & Decreased \\
\hline \multirow{11}{*}{ Fabaceae } & Alhagi maurorum Medik. & $\mathrm{He}$ & 0.453 & 0.562 & Increased \\
\hline & Astragalus campylorrhynchus F. \& M. & $\mathrm{Th}$ & 0.365 & 0.000 & decreased \\
\hline & Astragalus commixtus Bunge & $\mathrm{Th}$ & 0.478 & 0.000 & decreased \\
\hline & Astragalus oxyglottis M.Bieb. & $\mathrm{Th}$ & 0.105 & 0.000 & decreased \\
\hline & Astragalus pellitus Bunge & $\mathrm{He}$ & 0.118 & 0.000 & decreased \\
\hline & Medicago sativa $\mathrm{L}$. & $\mathrm{He}$ & 0.149 & 0.000 & decreased \\
\hline & Melilotus officinalis (L.) Pall. & $\mathrm{He}$ & 0.242 & 0.000 & decreased \\
\hline & Meristotropis xanthioides Vassilcz. & Geo & 0.000 & 0.369 & Increased \\
\hline & Sophora pachycarpa C.A.Mey. & $\mathrm{He}$ & 0.857 & 0.369 & decreased \\
\hline & Trigonella monantha C.A.Mey. & $\mathrm{Th}$ & 1.276 & 0.000 & decreased \\
\hline & Vicia villosa Roth & $\mathrm{He}$ & 0.359 & 0.000 & decreased \\
\hline Geraniaceae & Erodium oxyrrhynchum M.Bieb. & $\mathrm{Th}$ & 0.267 & 0.507 & Increased \\
\hline Iridaceae & Iris songarica Schrenk & Geo & 0.273 & 0.228 & decreased \\
\hline Juncaceae & Juncus inflexus L. & $\mathrm{He}$ & 0.242 & 0.193 & decreased \\
\hline \multirow{3}{*}{ Lamiaceae } & Marrubium vulgare L. & $\mathrm{He}$ & 0.453 & 0.562 & Increased \\
\hline & Perovskia abrotanoides Karel & $\mathrm{Ch}$ & 0.710 & 0.000 & decreased \\
\hline & Ziziphora tenuior $\mathrm{L}$. & $\mathrm{Th}$ & 0.309 & 0.000 & decreased \\
\hline Malvaceae & Malva neglecta Wallr. & $\mathrm{He}$ & 0.360 & 0.000 & decreased \\
\hline Nitrariaceae & Peganum harmala $\mathrm{L}$. & $\mathrm{He}$ & 1.293 & 1.811 & Increased \\
\hline \multirow{3}{*}{ Papaveraceae } & Fumaria vaillantii Loisel. & $\mathrm{Th}$ & 0.210 & 0.000 & decreased \\
\hline & Hypecoum pendulum $\mathrm{L}$. & $\mathrm{Th}$ & 0.161 & 0.000 & decreased \\
\hline & Roemeria hybrida (L.) DC. & $\mathrm{Th}$ & 0.273 & 0.000 & decreased \\
\hline \multirow{3}{*}{ Plantaginaceae } & Linaria simplex L. & $\mathrm{Th}$ & 0.093 & 0.000 & decreased \\
\hline & Plantago lanceolata $\mathrm{L}$. & $\mathrm{He}$ & 0.000 & 0.299 & Increased \\
\hline & Veronica biloba Schreb. ex L. & $\mathrm{Th}$ & 0.105 & 0.136 & Increased \\
\hline \multirow{8}{*}{ Poaceae } & Aegilops triuncialis L. & $\mathrm{Th}$ & 0.757 & 0.000 & decreased \\
\hline & Avena sterilis L. & $\mathrm{Th}$ & 0.367 & 0.000 & decreased \\
\hline & Boissiera squarrosa (Banks \& Soland.) Nevski & $\mathrm{Th}$ & 2.484 & 2.600 & Increased \\
\hline & Bromus danthoniae Trin. & $\mathrm{Th}$ & 2.120 & 1.393 & decreased \\
\hline & Bromus tectorum L. & Th & 5.025 & 6.452 & Increased \\
\hline & Elymus repens (L.) Gould & $\mathrm{He}$ & 0.111 & 0.000 & decreased \\
\hline & Eremopyrum bonaepartis (Spreng.) Nevski & $\mathrm{Th}$ & 2.782 & 1.295 & decreased \\
\hline & Hordeum murinum $\mathrm{L}$. & $\mathrm{Th}$ & 6.908 & 4.333 & decreased \\
\hline
\end{tabular}


Table 2. continued.

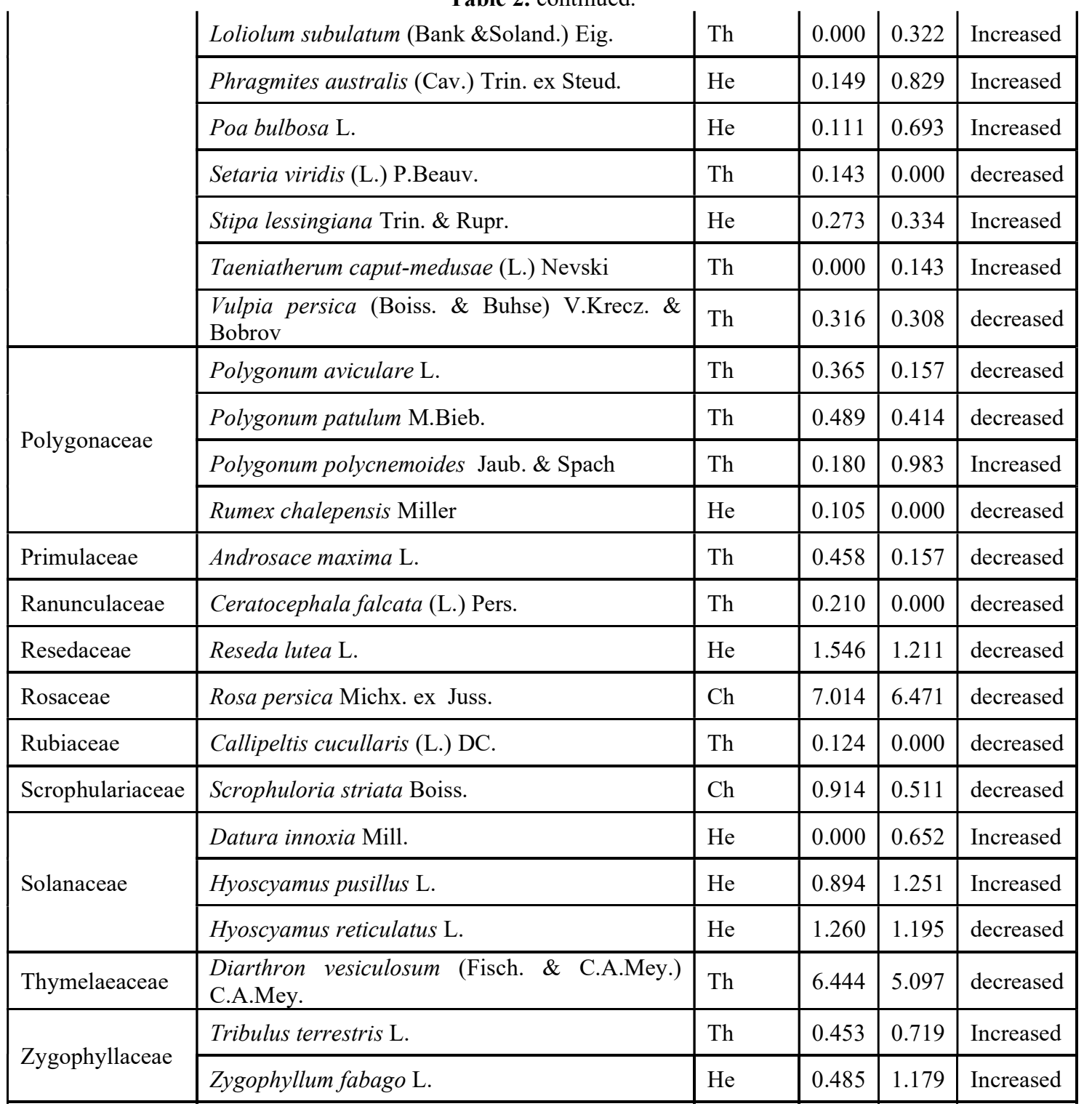

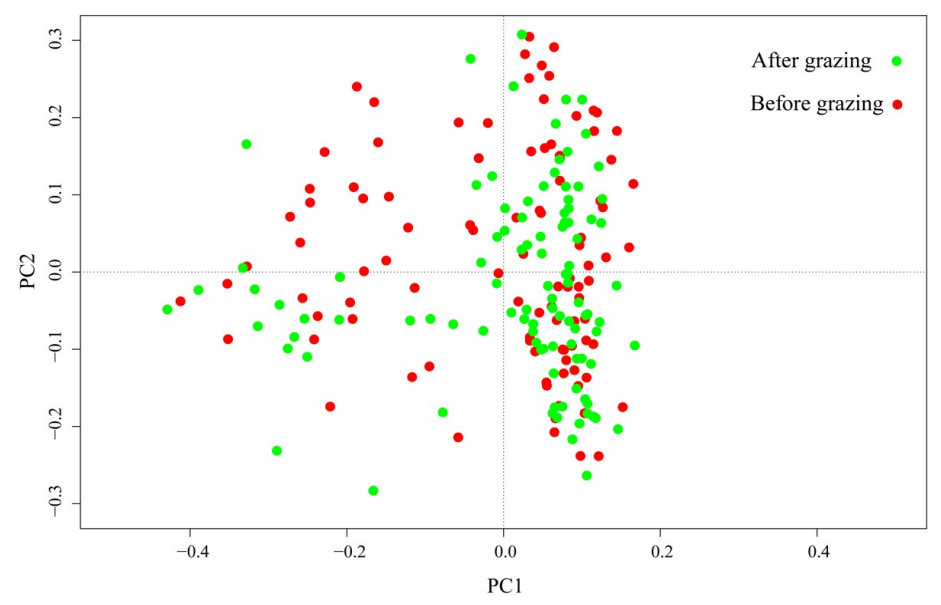

Figure 3. Transformation-based principal component analysis (tb-PCA) results showing species composition of plots for after and before overgrazing phases. Each circle denotes a plot. This graph reveals that the species composition of the study area was not differed in the before and after grazing phases. 


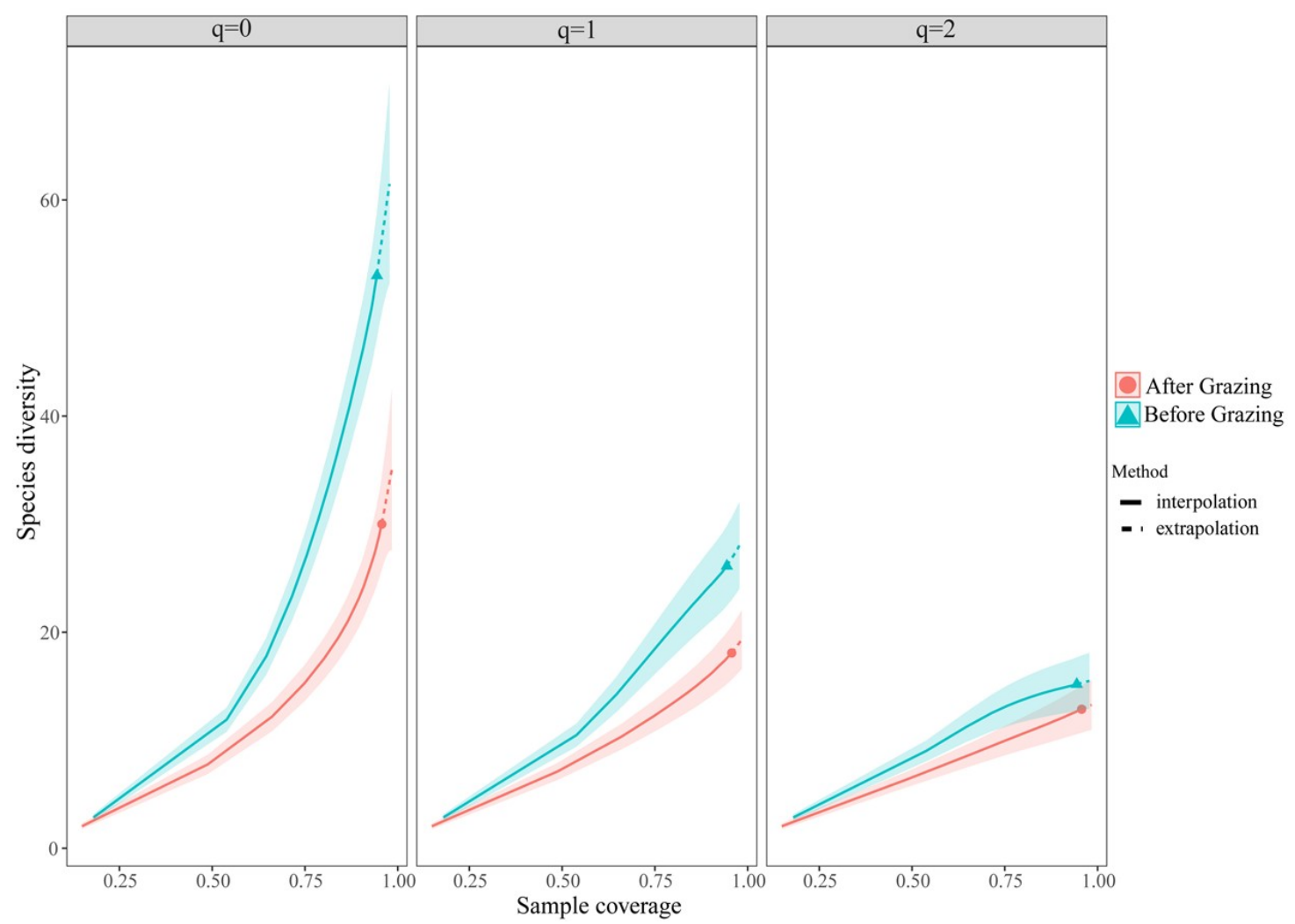

Figure 4. Coverage-based rarefaction and extrapolation curve comparing Hill species diversity for the before and after overgrazing phases. The shaded area represents the $95 \%$ confidence intervals which obtained by bootstrapping method with 999 replications. These results are showing the species richness $(q=0)$, the exponential of the Shannon diversity $(\mathrm{q}=1)$, and the reciprocal of the Simpson index for the two area.

\section{DISCUSSION}

Livestock overgrazing is one of the significant causes of habitat degradation in arid environments (Jeddi \& Chaieb, 2010). We studied an arid area subjected to long-term livestock overgrazing. The physiognomy, vegetation structure, and species diversity were compared before and after overgrazing to investigate the response of plant communities to the overgrazing in the study area.

Impacts of overgrazing on the physiognomy of plant communities in the area

Therophytes were the dominant plants in the area. The reported percent of this life-form are higher than the other areas reported by Atashgahi et al. (2018a), Jankju et al. (2012), and Memariani et al. (2009). However, our study area had a lesser amount of therophytes when compared to that of the Erfanian et al. (2019a). They suggested the therophytes as an excellent indicator of disturbance in an area. Thus, it can be inferred that our area is more disturbed than those studies that reported a lesser amount of therophytes, and it is less disturbed than that of the Erfanian et al. (2019a) which reported a higher amount of therophytes.

The decline of therophytes after overgrazing may be due to the fact that these species are ephemeral.
Haarmeyer et al. (2010) reported that the abundance of annuals was not affected by grazing in an arid area. The percent of chamaephytes and phanerophytes remained the same in both phases. Sampling error could be considered as the potential cause for the recorded variation in the other life-forms (i.e., chamaephytes and geophytes) (see Fig. 2).

Impacts of overgrazing on species composition of the area

The results of RIVI analyses revealed that most of the remained species after overgrazing are unpalatable plants. The dominance of unpalatable species in overgrazed lands was also reported by Friedel et al. (2003). The results of tb-PCA show that there is no distinction between plant communities before and after overgrazing. This finding indicates changing the species composition of an area is not one of the immediate effects of overgrazing in arid lands.

Impacts of overgrazing on the species diversity of the area

The decline of species richness (Fig. 4, $\mathrm{q}=0$ ) might be affected by the time of the sampling ephemeral plants might vanish from the area at the time of sampling for the after-overgrazing phase. The diversity of dominant species (Fig. 4, $\mathrm{q}=2$ 
column) is similar in the before and after overgrazing phases. Hosseini et al. (2020) suggested that increase in dominance of unpalatable plants could decrease the species diversity of an overgrazed area. Our results approved the equilibrium theory, which states that areas facing overgrazing for a long-history were not degraded after being overgrazed (Cingolani et al., 2005; Milchunas et al., 1988). Also, this finding suggests that heavy overgrazing could not affect the dominant species in an area. Furthermore, this finding suggests that unpalatable species are the dominant plants in the area. Although unpalatable species may seem undesirable in areas, this species could conserve species and functional diversity in overgrazed areas (Callaway et al., 2005).

\section{CONCLUSIONS}

The results of this study revealed that overgrazing caused a change in the RIVI of plant species. Overgrazing led to the dominance of unpalatable species in the area. In general, our results indicated that overgrazing in a degraded area could not affect the remaining plant communities. Exclusion cannot be applied in this area and areas with a similar condition. This finding should be considered in managing the remaining endemic vegetation of the area.

\section{ACKNOWLEDGEMENT}

The authors thank the Ferdowsi University of Mashhad for financial support (Project No. 43326). We acknowledge A. Basiri for field assistance, and M.R. Joharchi for determination of the collected plants.

\section{REFERENCES}

Atashgahi, Z., Ejtehadi, H., Mesdaghi, M. \& Ghasemzadeh, F. 2018a. Plant diversity of the Heydari Wildlife Refuge in northeastern Iran, with a checklist of vascular plants. Phytotaxa 340: 101-127.

Atashgahi, Z., Ejtehadi, H., Mesdaghi, M. \& Ghassemzadeh, F. 2018b. The existence of a unimodal or monotonic pattern in species richness and diversity along an elevational gradient: a case study in Heydari Wildlife Refuge, NE Iran. Nova Biologica Reperta 5: 291-298.

Behroozian, M., Ejtehadi, H. Memariani, F., Joharchi, M.R. \& Mesdaghi, M. 2019. Stipa richteriana (Poaceae) and Galium songaricum (Rubiaceae): two new additions of the Central Asian species to the flora of Iran. Nova Biologica Reperta 6: 326-333.

Callaway, R.M., Kikodze, D., Chiboshvili, M. \& Khetsuriani, L. 2005. Unpalatable plants protect neighbors from grazing and increase plant community diversity. Ecology 86: 1856-1862.
Chao, A., Chiu, C.-H. \& Jost, L. 2014a. Unifying species diversity, phylogenetic Diversity, Functional Diversity, and Related Similarity and Differentiation Measures Through Hill Numbers. Annual Review of Ecology, Evolution and Systematics 45: 297-324.

Chao, A., Gotelli, N.J., Hsieh, T. C., Sander, E.L., Ma, K.H., Colwell, R.K. \& Ellison, A.M. 2014b. Rarefaction and extrapolation with Hill numbers: A framework for sampling and estimation in species diversity studies. Ecological Monographs 84: 45-67.

Chao, A. \& Jost, L. 2012. Coverage-based rarefaction and extrapolation: Standardizing samples by completeness rather than size. Ecology 93: 25332547.

Cingolani, A.M., Noy-Meir, I. \& Díaz, S. 2005. Grazing effects on rangeland diversity: A synthesis of contemporary models. Ecological Applications 15: 757-773.

De Cáceres, M. \& Legendre, P. 2009. Associations between species and groups of sites: Indices and statistical inference. Ecology 90: 3566-3574.

De Cáceres, M., Legendre, P., Wiser, S.K. \& Brotons, L. 2012. Using species combinations in indicator value analyses. Methods in Ecology and Evolution 3: 973-982.

Eccard, J.A., Walther, R.B. \& Milton, S.J. 2000. How livestock grazing affects vegetation structures and small mammal distribution in the semi-arid Karoo. Journal of Arid Environments 46: 103-106.

Eftekhari Ahandani, S., Sheykh, V.B., Noura, N., Tabatabaee Yazdi, S.J. \& Akhzari, D. 2014. Identifying and prioritizing the appropriate places in the underground water supply of watershed system (case study: Golbahar watershed, Khorassan Razavi). Journal of Water and Soil Conservation 21: 1-30.

Ellison, A.M. 2010. Partitioning diversity 1. Ecology 91: 1962-1963.

Erfanian, M.B., Ejtehadi, H., Vaezi, J. \& Moazzeni, H. 2019a. Plant community responses to multiple disturbances in an arid region of northeast Iran. Land Degradation \& Development 30: 1554-1563.

Erfanian, M.B., Ejtehadi, H., Vaezi, J., Moazzeni, H., Memariani, F. \& Firouz-Jahantigh, M. 2019b. Plant community responses to environmentally friendly piste management in northeast Iran. Ecology and Evolution 9: 8193-8200.

Fallah, M., Farzam, M., Hosseini, V., Moravej, G. \& Eldridge, D.J. 2017. Termite effects on soils and plants are generally consistent along a gradient in livestock grazing. Arid Land Research and Management 31: 159-168.

Friedel, M. H., Sparrow, A. D., Kinloch, J.E. \& Tongway, D.J. 2003. Degradation and recovery processes in arid grazing lands of central Australia Part 2: Vegetation. Journal of Arid Environments 55: 327-348.

Geological Survey of Iran. 1986. Geologic quadrangle map of Iran (No. K-4).

Haarmeyer, D.H., Schmiedel, U., Dengler, J. \& Bösing, B.M. 2010. How does grazing intensity affect different vegetation types in arid Succulent Karoo, 
South Africa? Implications for conservation management. Biological Conservation 143: 588-596.

Hosseini, S., Ejtehadi, H., Memariani, F. \& Erfanian, M.B. 2020. Effects of slope aspect on plant diversity in Hezar Masjed summit, Khorassan Razavi province, Iran. Nova Biologica Reperta 7: 355-362.

Hsieh, T.C., Ma, K.H. \& Chao, A. 2016. INEXT: an R package for rarefaction and extrapolation of species diversity (Hill numbers). Methods in Ecology and Evolution 7: 1451-1456.

Illius, A.W. \& O'Connor, T.G. 1999. On the relevance of non-equilibrium concepts to arid and semi-arid grazing systems. Ecological Applications 9: 798-813.

Iran Meteorological Organization-Razavi Khorasan portal. 2018. The climate data of Khorassan Razavi Province. http://www.razavimet.ir/fa/node/38

Jankju, M., Mellati, F. \& Atashgahi, Z. 2012. Flora, life form and chorology of winter and rural range plants in the Northern Khorasan Province, Iran. Journal of Rangeland Science 1: 269-282.

Jeddi, K. \& Chaieb, M. 2010. Changes in soil properties and vegetation following livestock grazing exclusion in degraded arid environments of South Tunisia. Flora - Morphology, Distribution, Functional Ecology of Plants 205: 184-189.

Kimball, S. \& Schiffman, P.M. 2003. Differing effects of cattle grazing on native and alien plants. Conservation Biology 17: 1681-1693.

Legendre, P. \& Legendre, L. 2012. Numerical ecology ( $3^{\text {rd }}$ ed.). Elsevier.

Malki Sadabai, Z., Ejtehadi, H., Abrishamchi, P., Vaezi, J. \& Erfanian Taleii Noghan, M.B. 2017. Comparative study of autecological, morphological, anatomical and karyological characteristics of Acanthophyllum ejtehadii Mahmoudi \& Vaezi (Caryophyllaceae): a rare endemic in Iran. Taiwania 62: 321-330.

Memariani, F., Joharchi, M.R., Ejtehadi, H. \& Emadzade, K. 2009. A contribution to the flora and vegetation of Binalood mountain range, NE Iran: Floristic and chorological studies in Fereizi region. Ferdowsi University International Journal of Biological Sciences 1: 1-17.

Memariani, F., Zarrinpour, V. \& Akhani, H. 2016a. A review of plant diversity, vegetation, and phytogeography of the Khorassan-Kopet Dagh floristic province in the Irano-Turanian region (northeastern Iran-southern Turkmenistan). Phytotaxa 249: 8-30.

Memariani, F., Akhani, H. \& Joharchi, M.R. 2016 b. Endemic plants of Khorassan-Kopet Dagh floristic province in Irano-Turanian region: Diversity, distribution patterns and conservation status. Phytotaxa 249: 31-117.

Milchunas, D.G., Sala, O.E. \& Lauenroth, W.K. 1988. A generalized model of the effects of grazing by large herbivores on grassland community structure. The American Naturalist 132: 87-106.

Muenchow, J., Feilhauer, H., Bräuning, A., Rodríguez, E.F., Bayer, F., Rodríguez, R.A. \& von Wehrden, H. 2013. Coupling ordination techniques and GAM to spatially predict vegetation assemblages along a climatic gradient in an ENSO-affected region of extremely high climate variability. Journal of Vegetation Science 24: 1154-1166.

R Core Team. 2018. R: A language and environment for statistical computing. R Foundation for Statistical Computing.

Rahmanian, S., Hejda, M., Ejtehadi, H., Farzam, M., Pyšek, P. \& Memariani, F. 2020. Effects of livestock grazing on plant species diversity vary along a climatic gradient in northeastern Iran. Applied Vegetation Science 23: 551-561.

Randall, R. 2012. A global compendium of weeds ( $2^{\text {nd }}$ ed.). Department of Agriculture and Food, Western Australia.

Salgado-Luarte, C., Escobedo, V.M., Stotz, G.C., Rios, R.S., Arancio, G. \& Gianoli, E. 2019. Goat grazing reduces diversity and leads to functional, taxonomic, and phylogenetic homogenization in an arid shrubland. Land Degradation \& Development 30: 178-189.

Sullivan, S. \& Rohde, R. 2002. On non-equilibrium in arid and semi-arid grazing systems. Journal of Biogeography 29: 1595-1618.

Tadey, M. \& Souto, C.P. 2016. Unexpectedly, intense livestock grazing in arid rangelands strengthens the seedling vigor of consumed plants. Agronomy for Sustainable Development 36: 63.

Wickham, H. 2009. ggplot2: Elegant graphics for data analysis. Springer-Verlag.

Zar, J.H. 2010. Biostatistical analysis. Prentice-Hall.

How to cite this article:

Kadhum, S.M., Ejtehadi, H., Memariani, F. \& Erfanian, M.B. 2021. Evaluating changes in the plant communities after overgrazing in the Golbahar plain, northeast of Iran. Nova Biologica Reperta 7: 431-441. 